\title{
NON-DECREASING ECONOMIC GROWTH RATE OF INFLATION (NDEGRI) IN LIGHT OF EMPIRICAL STUDIES
}

\author{
Jan L. Bednarczyk \\ Kazimierz Pulaski University of Technology and Humanities in Radom, Radom, Poland \\ e-mail: jan.bednarczyk@wp.pl \\ ORCID: 0000-0002-7741-6296
}

\section{Katarzyna Brzozowska-Rup}

Kielce University of Technology, Kielce, Poland

e-mail: brzozows@poczta.fm

ORCID: 0000-0003-1231-8027

(C) 2019 Jan L. Bednarczyk, Katarzyna Brzozowska-Rup

This is an open access article distributed under the Creative Commons Attribution-NonCommercial-

-NoDerivs license (http://creativecommons.org/licenses/by-nc-nd/3.0/)

DOI: 10.15611/eada.2019.1.01

JEL Classification: E31, E52, E58, E63, E65.

\begin{abstract}
The article presents the results of estimating economic growth depending on the inflation levels in selected countries. The results were obtained by means of regression splines, in particular, cubic splines and a B-spline curve. The method applied helps to identify both the area of NonDecreasing Economic Growth Rate of Inflation and inflation for which the rate of growth reaches its maximum. The calculations and graphic presentations demonstrate that maximum rates of economic growth were reached in inflation ranges of 5\%-15\% for Poland and 3\%-16\% for the G-20 countries studied. The data analysis leads to the conclusion that central bank margins for their accommodative monetary policies in the studied countries can be wider than it is implied by the doctrinal bases of the inflation targeting policy or its more restrictive version - strict inflation targeting.
\end{abstract}

Keywords: low inflation trap, central bank`s inflation target, regression splines.

\section{Introduction and literature review}

The question of an optimal inflation rate is a key problem and the subject of lively debate in contemporary macroeconomics. It originated from a discussion about the extent and significance of price stability to the long-term equilibrium of economic growth that has been continuing since the 1960s between post-Keynesian and Neoclassical (post-monetarist) proponents. M. Friedman [1969] and his followers [e.g. Schmitt-Grohè, Uribe 2009] have opted for full price stability or even moderate 
deflation as the condition of the equilibrium, whereas their adversaries regard moderate inflation as a factor stabilising or even fostering economic prosperity.

Supporters of full price stability (moderate deflation) base their arguments on dependences of the Friedman rule, which implies a postulate of maintaining zero interest rates in the long term in order to balance the marginal rate of revenue from cash reserves against the marginal cost of additional money issues by the state. On the other hand, Keynes posited arguments for moderate price rises claiming that rising prices are the natural consequences of production growth and "no-one is entitled to the privilege of buying at prices that are low only because production is low' [Keynes 2007].

Keynes's ideas were continued by J. Tobin [1965], in particular. He believed moderate inflation encouraged market players to spend their cash, which in turn contributes to boosting overall demand and production in the economy (the Tobin Effect). It also enforces, in his opinion, downward flexibility of wages as real wages diminish, which may have a positive impact on the profitability of production and consequently its growth [Tobin 1972].

The possibility of avoiding the zero lower bound of nominal interest rates (ZLB) and its attendant adverse effects on economic growth is a commonly cited, key argument for moderate inflation [Blanchard, Dell Ariccia, Mauro 2010; Di Bartolomeo, Tirelli, Acocella 2015].

Among other studies of factors affecting the dynamics of economic growth (in particular inflation), those of fixed asset investments and their effect on economic growth, examining the nature of causality, especially as defined in neoclassical growth models (by Solow, Mankiw-Romer-Weil, and others), need to be mentioned. Research by Blomstrom, Lipsey and Zejan [1993], Podrecca, Carmeci [2001], Tvaronavičius and Tvaronavičiene [2008], Kononenko, Repin [2016], using data for a variety of country groups and periods, indicates that the scale and dynamics of fixed-asset investment cannot be treated as a factor determining economic growth since this is the rate of economic growth that defines the scale and rate of growth in these investments. Knight and Ding [2009] explored the dependences between the changes of fixed asset investment and the rate of economic growth in China, concluding that the dependences can operate both ways. They state, however, that endogenous models of economic growth are better than neoclassical models at describing the dependence between the growth of fixed-asset investment and economic growth.

In Poland, studies of inflation as a factor determining the rate of economic growth (optimal inflation rate) have been conducted by Baranowski [2008], Bednarczyk [2005], and Błaszczuk [2016], among others. Bednarczyk's research has produced the hypothesis of neutral inflation (Non-Decreasing Economic Growth Rate of Inflation, NDEGRI ${ }^{1}$ ). This assumes there is a range of inflation

${ }^{1}$ Non-Decreasing Economic Growth Rate of Inflation. 
rates within which individual economies (groups of economies) attain maximum rates of real GNP growth given stabilised inflationary expectations. Rates of inflation below that range increase the risk of deflationary-stagnation processes in an economy (the problem of a low inflation trap) [Bednarczyk, Misztal 2016], whereas higher rates threaten to 'unanchor' (fuel) inflationary expectations, to raise the social costs of inflation, and consequently to slow economic growth. The idea of Non-Decreasing Economic Growth Rate of Inflation (NDEGRI) corresponds to studies where the dependence between inflation and economic growth has been illustrated as a parabolic, non-monotonic, convex curve [Błaszczuk 2016; Baranowski 2008], yet places more emphasis on the issue of excessively low inflation as a barrier to economic growth.

The question of excessively low inflation has been raised by Akerlof, Dickens and Perry [1996], Pollin and Zhu [2005], Blanchard, Dell Ariccia and Mauro [2010], Di Bartolomeo, Tirelli and Acocella [2015], and many others. For instance, Pollin and Zhu examined data for 80 countries covering 1961-2000 and concluded that inflation in the range $15 \%-18 \%$ is associated with moderate benefits to the growth of real GNP. The threshold rate for medium-income countries was 14\%-16.3\%. Blanchard, Dell Ariccia and Mauro [2010, p.11] see no risk to the economic growth of developed countries even at rates of inflation double the $2 \%$ inflation targets.

This paper concerns a very specific issue, namely the relation between the rates of price growth and of economic growth. The research problem is the identification of an inflation rate at which economic growth is not slowed (stemmed). It is the objective of this paper to estimate ranges of inflation rates within which countries showed the best economic growth, based on annual figures for Poland and five G20 economies (the United States, China, India, Brazil and Mexico) ${ }^{2}$ for the years 1995-2015 (available at http://www.imf.org/en/data). Another aim is the indication of the degree of freedom of central banks at accommodating economic booms without substantial modifications to the nature of inflationary expectations.

\section{Methods}

In searching for a model to describe the relationship between a scalar response $\mathrm{Y}$ and one or more explanatory variables $\mathrm{X}$, the problem of parametric regression models is most commonly addressed in practice:

$$
E[Y \mid X]=f(X, \alpha),
$$

where $X$ and $Y$ are vectors of the independent and dependent variables, respectively (in our case, the length of the vectors is $N$ ), and $\alpha$ is the vector of parameters (the regression coefficients).

${ }^{2}$ Leading G-20 economies that experienced periods of higher (Brazil, Mexico), moderate (China, India), and low inflation (the US) in 1995-2015. 
Analysis of the impact of inflation levels on economic growth shows that the real dependence between these variables differs in adjacent areas of inflation's variability. The force and direction of inflation's effect on the rates of economic growth are supposed to depend on inflation levels (high inflation generally implies adverse growth shifts, whereas low inflation generates positive changes), which in turn leads one to assume a non-linear dependence between inflation and growth [Baranowski 2008; Błaszczuk 2016]. Intuitively, an attempt may therefore be made to define $f$ 'piecewise'. The literature refers to such approaches as regression splines. The regression spline is one of the most important non-parametric regression techniques and can be seen as an extension of linear models that automatically models nonlinearities and interactions between variables. It should be noted that nonparametric methods are an alternative approach to the classical regression method, constructed to solve regression problems when some of the restrictive assumptions of the classical linear model are not fulfilled, therefore they are characterized by a greater flexibility and possibility of applications.

The method consists in sorting values of $X$ in a non-descending order and then determining a sequence of points $\left\{\zeta_{k}\right\}_{k=1, \ldots K-1}$ and dividing a variable's domain into $K$ disjoint ranges $\left\langle\zeta_{k}, \zeta_{k+1}\right\rangle$, where $K \leq N$. Function $f_{k}\left(X, \alpha_{k}\right)$ is matched to data in each range, which represents $f$ in the given range. In practice, where an analytical form of $f_{k}$ cannot be derived from the dependence diagram of $\mathrm{Y}$ on $\mathrm{X}$, the function is assumed to be a polynomial. As a result, the method helps to describe a dependent variable by means of function $f$ composed of polynomial pieces. The points $\zeta_{k}$ are referred to as knots (control points along an estimated curve), are normally unknown and should be obtained from experimental data. Note that the ends of the function's definite range may be both finite and infinite. The presented analysis assumes: $\zeta_{0}=\min _{X}, \zeta_{K}=\max _{X}$.

If all the component functions $f_{k}\left(X, \alpha_{k}\right)$ are polynomials, $f$ is called a multiphase or splined polynomial, with the 'splines' being a particular class of splined polynomials. Two basic classes of splines are distinguished: with fixed knots (determined prior to experiments) and with free knots to be derived from data [Hayes 1974; Schumaker 1981; de Boor 2001; Muciek 2012].

To sum up, the function $f(X, \alpha)$ describing the model (1) can be represented in the following additive format:

$$
f(X, \alpha)=\sum_{k=1}^{K} f_{k}\left(X, \alpha_{k}\right)
$$

whereas solving this problem by means of the splines method involves defining

$$
\begin{gathered}
f(X, \alpha) \text { as } \\
f(X, \alpha)=\sum_{m=1}^{M} \alpha_{m} h_{m}(X)
\end{gathered}
$$

where the function $h_{m}: R \rightarrow R$ is the $m^{\text {th }}$ transformation of $X$, referred to as the base function. The function $f$, defined above, is referred to as the $M$ degree spline 
function or spline $M$ (in short, $M$-spline). Where $f$ is a multiphase polynomial, the set of base functions can be represented with the following functions:

$$
\begin{gathered}
h_{j}(X)=X^{j-1}, j=1, \ldots, M \\
h_{M+i}(X)=\left(X-\zeta_{j}\right)_{+}^{M-1}, i=1, \ldots, K
\end{gathered}
$$

and an $M-$ spline is expressed as the sum of the power series:

$$
f(X)=\sum_{i=1}^{M} \alpha_{i} X^{i-1}+\sum_{j=1}^{K} \beta_{j}\left(X-\zeta_{j}\right)_{+}^{M-1}
$$

where $(\cdot)_{+}$denotes a truncated function defined as:

$$
\left(X-\zeta_{j}\right)_{+}=\max \left\{0, X-\zeta_{j}\right\}=\left\{\begin{array}{cc}
X-\zeta_{j} & \text { if } X>\zeta_{j} \\
0 & \text { otherwise }
\end{array}\right.
$$

Estimation of the model requires the construction of the so-called experimental matrix, which for the model set with (4) takes the following form:

$$
\left[\begin{array}{cccccccc}
1 & x_{1} & x_{1}^{2} & \cdots & x_{1}^{M-1} & \left(x_{1}-\zeta_{1}\right)^{M-1} & \cdots & \left(x_{1}-\zeta_{K}\right)^{M-1} \\
1 & x_{2} & x_{2}^{2} & \cdots & x_{2}^{M-1} & \left(x_{2}-\zeta_{1}\right)^{M-1} & \cdots & \left(x_{2}-\zeta_{K}\right)^{M-1} \\
& & & & & \vdots & & \\
1 & x_{N} & x_{N}^{2} & \cdots & x_{N}^{M-1} & \left(x_{N}-\zeta_{1}\right)^{M-1} & \cdots & \left(x_{1}-\zeta_{K}\right)^{M-1}
\end{array}\right] .
$$

A fourth-degree spline $(M=4)$, referred to as a cubic spline, is a special case of (4) with common practical applications. Assuming three knots are distinguished, the spline can be expressed as

$$
S(X)=1+X+X^{2}+X^{3}+\left(X-\zeta_{1}\right)_{+}^{3}+\left(X-\zeta_{2}\right)_{+}^{3}+\left(X-\zeta_{3}\right)_{+}^{3} .
$$

It should be noted that since the columns of the foregoing matrix may be highly correlated and the experimental matrix may be high, the splines determined with the aid of truncated polynomials may be numerically unstable. Practice suggests ' $B$-splines', with fourth-order splines or cubic $B$-splines as their essential group, are more (numerically) effective [Muciek 2012]. B-splines are defined by both $M$ - degree of spline polynomials, series of knots and of control points $\theta_{1}, \ldots, \theta_{M-K}$ (the set of points deciding the shape of a curve being matched).

Difficulties of the method consist in establishing the optimum degree of the splines and the number and location of the knots. The choice of knots is an important problem when working with B-splines. Selecting too many leads to an overfitting of the data, on the other hand, too few knots provide an underfitting. Degrees of freedom are frequently selected on the basis of a scatter diagram and subsequently verified as the quality and correctness of the final model are tested. Some automatic numerical schemes for solving these problems were proposed, for example, by Friedman and Silverman [1989]. 


\section{Empirical part}

The introduction already mentioned the two data groups which are being analysed, that is, the annual time series of real GDP and inflation growth for Poland and selected G-20 countries. 4th-degree splines with arbitrarily set knots are estimated for each group and the results of the $B$-spline estimation are illustrated (Figures 1 and 2). The models have been estimated by means of the ordinary least-squares method available with GRETL and with the aid of the $\mathrm{R}$ software functions discussed above. The dependence of economic growth on inflation was estimated a number of times and the model best matching real data selected based on the criteria of the model parameter significance, residual properties, minimization of the root mean square error, and information criteria (AIC, BIC, HQC). Two cubic spline models were considered, namely:

1) those containing few knots (defining the generally accepted ranges of inflation variability, i.e. $A 0$ - inflation below zero, $A 1$ - inflation values in the range $[0,3)], A 2-$ inflation values in the range $[3,10)], A 3$ - inflation above 10] that is, model 1 for Poland and model 3 for countries outside the Eurozone,

2) models containing a number of evenly spaced knots: model 2 for the data concerning Poland and model 4 for countries outside the Eurozone area. Additional variables were introduced for the purposes of the estimation: $K$ - set number of knots.

The dependent and independent variables are subsequently denoted as $y_{t}$ and $C P I_{t}$, respectively.

The first model (hereafter referred to as model 1) applies to data observable in Poland in 1995-2015. A cubic spline was used with knots in the points $\left(\zeta_{i}, i=0, \ldots, 3\right):-1.4 ; 0 ; 3 ; 10$, respectively :

$$
\begin{aligned}
& \hat{y}_{t}=-11.782 C P I_{t}-12.486 C P I_{t}^{2}-4.471 C P I_{t}^{3}+4.471\left(C P I_{t}-\zeta_{0}\right)_{+}^{3} \\
& \begin{array}{llll}
(2.644) & (2.524) & (0.909) & (0.909)
\end{array} \\
& \begin{array}{llll}
(0.000) & (0.000) & (0.000) & (0.000)
\end{array}
\end{aligned}
$$

The results show the coefficients, standard deviations and the p-value for each of the estimated coefficients. These results are important and interesting for many reasons. All the factors included in the model are statistically significant. It should also be noted that an adjusted $\mathrm{R}$ squared $=0.868$ and $\mathrm{R}$ Square $=0.888$ mean that the model successfully explains almost $90 \%$ of the variance in economic growth in Poland, while the Durbin-Watson statistic = 2.892 indicates that there is no autocorrelation in the residuals. The spline regression parameters are expressed in units of the Y-variable, but are not easy for non-mathematicians to interpret [Newson 2000]. Typically, models of this type are interpreted using graphs.

Model 2 presents a cubic spline for economic growth in Poland, with the equally spaced knots selected as: $\zeta_{0}=-1 \approx \min _{X}, \zeta_{i}=\zeta_{i-1}+2, i=1, \ldots, 14$ : 


$$
\begin{aligned}
& \hat{y}_{t}=-13.341 C P I_{t}-13.911 C P I_{t}^{2}-4.988 C P I_{t}^{3}+4.987\left(C P I_{t}-\zeta_{0}\right)_{+}^{3} \\
& \begin{array}{llll}
(3.610) & (3.432) & (1.238) & (1.237)
\end{array}
\end{aligned}
$$

Similarly, all the coefficients in the model are significantly different from zero. An adjusted $\mathrm{R}$ squared $=0.836$ and $\mathrm{R}$ Square $=0.861$ reveal a high adjustment of the model to real data and the Durbin-Watson statistic $=2.620$ signifies the errors are uncorrelated.

Model 3 describes economic growth variations for selected G-20 countries, with the cubic spline determined for the following four knots: $-1.4,0,3,10,20$.

$$
\begin{aligned}
& \hat{y}_{t}=-5.935 C P I_{t}-4.585 C P I_{t}^{2}-1.084 C P I_{t}^{3}+1.085\left(C P I_{t}-\zeta_{0}\right)_{+}^{3} \\
& \begin{array}{llll}
(1.282) & (0.825) & (0.197) & (0.198)
\end{array} \\
& \begin{array}{llll}
(0.000) & (0.000) & (0.000)
\end{array}
\end{aligned}
$$

$\mathrm{R}$ Square $=0.552$, Adjusted R Square $=0.541$, Durbin-Watson Statistic $=2.320$.

The next model, 4, concerns countries outside the Eurozone. A cubic spline with equally spaced knots: $\zeta_{0}=-1 \approx \min _{X}, \zeta_{i}=\zeta_{i-1}+2, i=1, \ldots, 13, \zeta_{K}=34$ :

$$
\begin{array}{cccc}
\hat{y}_{t}=-6.007 C P I_{t}-4.744 C P I_{t}^{2} & -1.113 C P I_{t}^{3} & 1.115\left(C P I_{t}-\zeta_{0}\right)_{+}^{3} \\
(1.429) & (0.861) & (0.209) & (0.209) \\
(0.000) & (0.000) & (0.000) & (0.000)
\end{array}
$$

$$
\begin{array}{cc}
-0.028\left(C P I_{t}-\zeta_{11}\right)_{+}^{3} & -0.023\left(C P I_{t}-\zeta_{12}\right)_{+}^{3} \\
(0.011) & (0.011) \\
(0.017) & (0.012)
\end{array}
$$

R Square $=0.583$, Adjusted R Square $=0.565$, Durbin-Watson Statistic $=1.320$.

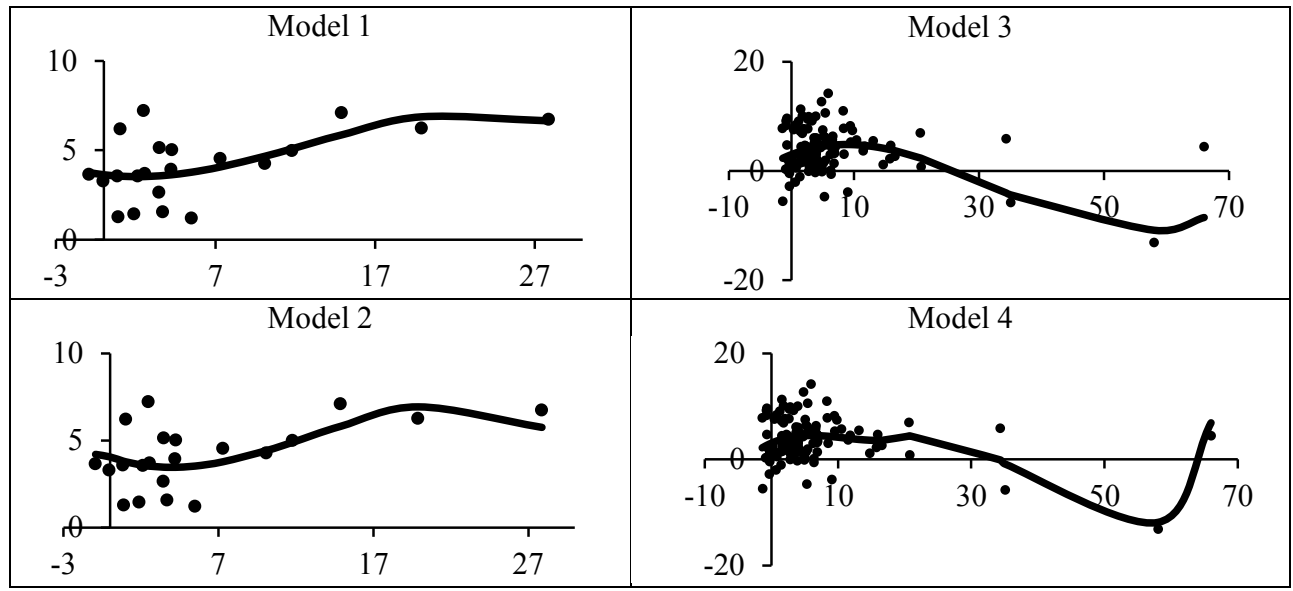

Fig. 1. The real and estimated (by the splines regression) economic growth values depending on the level of inflation

Source: the authors' own research. 
With regard to selected G-20 countries, the estimated models (3 and 4) successfully explain away over half of the variance in economic growth. Modifications with a view to improving the fit of the model will be the subject of the authors' continuing research.

Figure 1 illustrates the matching of the estimated models to real data. The left column contains the results derived from data concerning Poland, while the right one relates to countries outside the Eurozone. The continuous line indicates the theoretical values based on the above models.

In order to estimate the possible range of economic growth variations as dependent on inflation, we used the effects package available with $\mathrm{R}$, which creates graphic effect displays for various statistical models. The way this works with regression spline models is illustrated in the Figure 2.

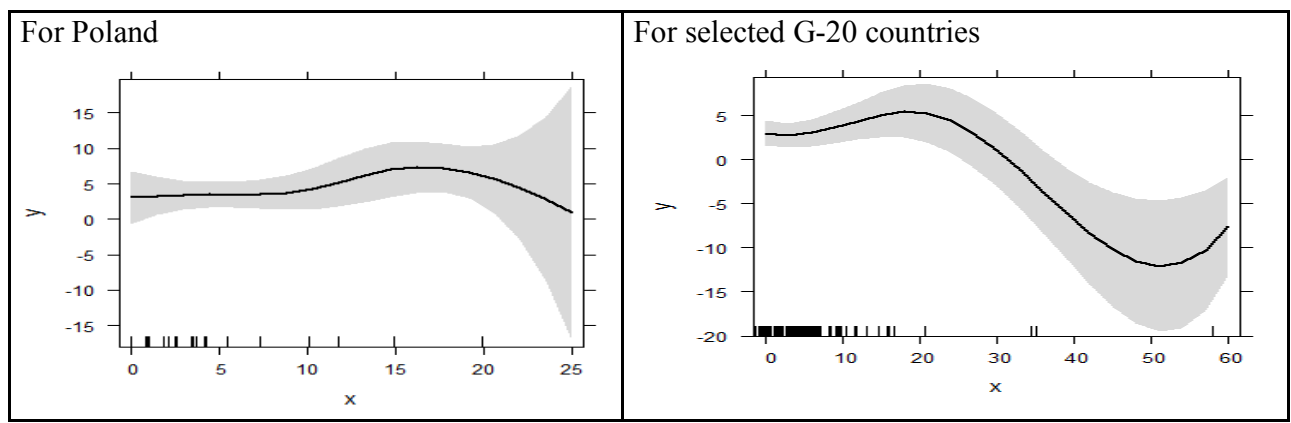

Fig. 2. The predicted values of economic growth depending on inflation from 1995 to 2015 (solid line) with a $95 \%$ confidence band (shading)

Source: the authors' own research.

In the right graph, the predicted values of economic growth increase as inflation rises from $3 \%$ to $16 \%$. It is worth noting that the lines of confidence bands for selected G-20 countries are parallel, while the left diagram does not show such regularity. In the left graph, the grey confidence band widens as inflation increases, indicating there are few observations with high inflation scores and hence less confidence in predictions. It should be noted for Poland (the left curve) that the confidence interval for economic growth remains similar, $2 \%-5 \%$, for inflation varying from $2.2 \%$ to $8.3 \%$. The analysis confirms that the influence of inflation on economic growth depends on the inflation levels.

\section{Conclusion}

Flexibility (a distinct improvement on the classic model of polynomial regression) is the advantage of the method introduced here, which allows for the description and examination of abrupt shifts of a modelled variable's trend. Although its 
practical difficulty consists in the fact that the shape of the spline depends on the correct selection of the number and precise location of knots, which is a highly complex issue, this analysis generates unambiguous results, namely that the nature of the dependence described here remains steady in the given ranges, regardless of the knot selection.

It is worth noting that the method helps to identify both the area of NonDecreasing Economic Growth Rate of Inflation and inflation for which the growth is maximum. Finally, the calculations and graphic presentations (Figures 1 and 2) demonstrate that the maximum rates of economic growth were reached in the inflation ranges of $5 \%-15 \%$ for Poland and 3\% - 16\% for the G-20 countries studied. Non-Decreasing Economic Growth Rate of Inflation (NDEGRI) may be higher than the inflation targets adopted by the countries surveyed. For instance, it may reach above $3 \%$ in the US and above $5 \%$ in Poland, etc. These observations also suggest that the central banks of these countries probably enjoy a greater freedom of accommodating economic growth using monetary policy instruments than the desiderata of the inflation targeting policies would imply, especially in their more restrictive varieties (strict inflation targeting).

\section{Bibliography}

Akerlof G.A., W.T. Dickens, G.L. Perry, 1996, The macroeconomics of low inflation, Brookings Papers on Economic Activity, 1.

Baranowski P., 2008, Problem optymalnej stopy inflacji w modelowaniu wzrostu gospodarczego, Wydawnictwo Biblioteka, Łódź.

Bednarczyk J.L., 2005, Stabilność cen a kondycja gospodarki. Uwagi o polityce stabilizacji cen w krajach Unii Europejskiej, Monografie i opracowania naukowe. Finanse, Pietrzak B. (red.), SGH i Kolegium Zarządzania i Finansów, Warszawa.

Bednarczyk J.L., P. Misztal, 2016, Czy strefa euro zmierza $w$ kierunku pułapki niskiej inflacji?, Ekonomista, 4.

Blanchard O., Dell Ariccia G., Mauro P., 2010, Rethinking macroeconomic policy, IMF Staff Position Note, SPN/10/03.

Blomstrom M., Lipsey R.E., Zejan M., 1993, Is fixed investment the key to economic growth? NBER Working Paper, no. 4436.

Błaszczuk D.J., 2016, A simple four-step procedure of parabolic B curve determination for OECD Countries in 1990Q1 - 2015Q41, Economics and Business Review, 2(16)

De Boor C., 2001, A Practical Guide to Splines, Revised Edition, Springer

Di Bartolomeo G., Tirelli P., Acocella N., 2015, The comeback of inflation as an optimal public finance tool, International Journal of Central Banking, 11(1).

Friedman M., 1969, The Optimum Quantity of Money and Other Essays, Aldine, Chicago.

Friedman J., Silverman B., 1989, Flexible parsimonious smoothing and additive modelling (with discussion and response), Technometrics, 31 .

Hayes J.G., 1974, Numerical methods for curve and surface fitting, J. Inst. Math. Appl., bf 10.

Keynes J.M., (reprinted 2007), General Theory of Employment, Interest and Money, Macmillan, London.

Knight J., Ding S., 2009, Why does China invest so much?, University of Oxford, Department of Economics, Discussion Paper Series, no. 441. 
Kononenko I., Repin A., 2016, The regularity of the country`s GDP growth rate changes influence on the volume of gross fixed capital formation, download from: https://www.researchgate.net/ publication/312128472_The_Regularity_of_the_Country's_GDP_Growth_Rate_Changes_Influe nce_on_the_Volume_of_Gross_Fixed_Capital_Formation (28.01.2019).

Muciek A., 2012, Wyznaczanie modeli matematycznych $z$ danych eksperymentalnych, download from: http://www.dbc.wroc.pl/Content/19612/muciek_wyznaczanie_modeli.pdf (18.05.2017).

Newson R., 2000, B-splines and splines parameterized by their values at reference points on the $X$ axis, Stata Technical Bulletin 57: 20-27, Reprinted in Stata Technical Bulletin Reprints, 10, download from: http://www.stata.com/products/stb/journals/stb57.html (18.09.2017)

Podrecca E., Carmeci G., 2001, Fixed investment and economic growth: New results on causality, Applied Economics, vol. 33, issue: 2.

Pollin R., Zhu A., 2005, Inflation and economic growth: Cross-Country, non-linear analysis, Political Economy Research Institute Working Paper Series, No. 109, University of Massachusetts, Amherst, October.

Schmitt-Grohè S., Uribe M., 2009, The optimal rate of inflation, download from:

http://www.ecb.europa.eu/events/pdf/conferences/monetaryeconomics/item1_paper.pdf (06.05.2017).

Schumaker L.L., 1981, Spline Functions: Basic Theory, Wiley, New York.

Tobin J., 1965, Money and economic growth, Econometrica, vol. 33, no. 4, October.

Tobin J. 1972, Inflation and unemployment, American Economic Review, 62(1).

Tvaronavičius V., Tvaronavičiene M., 2008, The role of fixed investments in the economic growth of a country: Lithuania in a European context, Journal of Business, Economics and Management, 9:1.

\section{INFLACJA NIESPOWALNIAJACA WZROSTU GOSPODARCZEGO (NDEGRI) W ŚWIETLE BADAŃ EMPIRYCZNYCH}

Streszczenie: W pracy zaprezentowano wyniki szacowania wysokości tempa wzrostu gospodarczego w zależności od poziomu inflacji w wybranych krajach, uzyskane metodą regresji sklejanej, w szczególności tzw. splajnów kubicznych i $B$-splajnów. Zastosowana metoda pozwala nie tylko na zidentyfikowanie przedziału inflacji niespowalniającej wzrostu gospodarczego, ale również wysokości inflacji, przy której wzrost gospodarczy osiąga najwyższą wartość. Obliczenia i prezentacje graficzne wskazują, że najwyższe stopy wzrostu gospodarczego były osiągane przy stopach inflacji mieszczących się w przedziale $5-15 \%$ w przypadku Polski oraz w przedziale $3-16 \%$ w przypadku badanych krajów G-20. Z analizy danych wynika, że margines dla akomodacyjnej polityki pieniężnej banków centralnych w badanych krajach może być większy, niżby to wynikało z doktrynalnych podstaw polityki bezpośredniego celu inflacyjnego, zwłaszcza w jej bardziej restrykcyjnej wersji.

Słowa kluczowe: pułapka niskiej inflacji, cel inflacyjny banku centralnego, regresja funkcji sklejanych. 